\title{
THE ACTION OF CLOMIPHENE IN THE EWE
}

\author{
D. R. LINDSAY* AND T. J. ROBINSON \\ Department of Animal Husbandry, University of Sydney, \\ Sydney, N.S.W. 2006, Australia
}

(Received 18th November 1969)

\begin{abstract}
Summary. Three tests are described, two each with thirty-six entire and one with fifty-six spayed ewes, in which the action of clomiphene citrate was characterized in the sheep. It was found to suppress pituitary activity, to induce behavioural oestrus and to have a grossly stimulatory action on the uterus in that it induced a high incidence of hydrops uteri. It is concluded that clomiphene acts in the ewe as a weak oestrogen but differs qualitatively from true oestrogen in its effect on the uterus.
\end{abstract}

\section{INTRODUGTION}

The successful use of clomiphene citrate for the induction of ovulation in anovulatory women (Greenblatt, 1961; Swyer, 1963) raises the question of its use for a similar purpose in anoestrous animals. This paper describes the physiological effects of its use in entire and spayed crossbred ewes, alone and in combination with progesterone and oestrogen, in the anoestrous period. Three tests were conducted, two each with thirty-six entire ewes and one with fifty-six spayed ewes between October and December, a period during which crossbred ewes in Australia normally are in a state of absolute or relative anoestrus. The tests were carried out at the Sheep and Wool Research Unit, University of Sydney, Camden, N.S.W., in 1966.

\section{MATERIALS AND METHODS}

\section{Design of the tests}

Tests 1 and 2. Thirty-six, mature, multiparous Border Leicester $\times$ Merino ewes were used in each test, incorporated into a factorial design. Each test was designed to examine the effect on ovulation and oestrus of clomiphene at three dose levels, given as a single or as multiple doses, with or without priming with progestagen.

Test 1 incorporated the following factors:

Dose of clomiphene (mg)

Number of injections of clomiphene
-30 versus 90 versus 270

-1 versus 3 at daily intervals

* Present address: Institute of Agriculture, University of Western Australia, Nedlands, W.A. 6009. 
Timing of clomiphene relative - Without progestagen versus to progestagen after cessation of progestagen versus before cessation of progestagen

Factorial $3 \times 2 \times 3 ; \mathrm{n}=2 ; \mathrm{N}=36$.

Test 2 involved treatment of all ewes with progestagen, followed by clomiphene, and incorporated the following factors:

Dose of clomiphene (mg)

Number of injections of clomiphene
-3.3 versus 10 versus 30

-1 versus 3 at daily intervals

Factorial $3 \times 2 ; \mathrm{n}=6 ; \mathrm{N}=36$.

In addition, eleven animals served as controls for both tests: five received no treatment; six were treated with progestagen alone.

Test 3. Fifty-six, 4-year-old, spayed Border Leicester $\times$ Merino ewes were incorporated into a factorial test designed to examine the effect of clomiphene on oestrous behaviour. Clomiphene was used either alone or in combination with a small dose $(15.6 \mu \mathrm{g})$ of oestradiol benzoate (ODB) to examine both its oestrogenic and anti-oestrogenic activities. All ewes were primed with progestagen.

The test incorporated the following factors:

Dose of clomiphene $(\mathrm{mg}) \quad-0$ versus 1.0 versus 3.2 versus 10.0

Dose of ODB $(\mu \mathrm{g})$ -0 versus $15 \cdot 6$

Factorial $4 \times 2 ; \mathrm{n}=7 ; \mathrm{N}=56$.

\section{Administration of hormones}

Progestagen (Cronolone, Searle) was administered for 12 days by intravaginal sponges, prepared as described by Robinson (1965) and impregnated with $30 \mathrm{mg}$ Cronolone.

Clomiphene was administered intramuscularly in aqueous solution. In Test 1 , multiple doses were given in three equal proportions at 24-hr intervals, commencing in the progestagen-treated ewes either $48 \mathrm{hr}$ before withdrawal of the intravaginal sponges or at the time of withdrawal. In Test 2, all injections, single or multiple, commenced on withdrawal of the sponges while in Test 3, the single injection was given $24 \mathrm{hr}$ after withdrawal.

Oestradiol benzoate was given to half the ewes in Test 3 as a single intramuscular injection of $15.6 \mu \mathrm{g}$ in $1 \mathrm{ml}$ oil, at the same time as clomiphene.

\section{Conduct of the tests}

Oestrus was detected by the use of ten rams fitted with 'Sire-sine' harnesses and crayons (Radford, Watson \& Wood, 1960). Rams were joined on the day of first injection of clomiphene, and ewes were inspected for oestrus daily thereafter.

The condition of the ovaries and uteri of ewes in Tests 1 and 2 was determined by laparotomy 48 to $60 \mathrm{hr}$ after the onset of oestrus or, in the absence of oestrus, 10 days after the withdrawal of progestagen.

The data were analysed using standard analysis of variance and $\chi^{2}$ tests. 
Control ewes

\section{RESULTS}

The eleven control ewes were with the teaser rams for 17 days before laparotomy. Six ovulated, of which five exhibited oestrus. The remainder had quiescent ovaries typical of anoestrus. Hence, the flock as a whole was in a state of partial anoestrus.

Entire ewes-Tests 1 and 2

Table 1 shows a similar pattern of results in each test, despite a nine-fold reduction of dose of clomiphene in Test 2.

\section{TABLE 1}

TESTS 1 AND 2-MAIN EFFECTS ON ENTIRE 'ANOESTROUS' EWES OF TREATMENT WITH CLOMIPHENE

\begin{tabular}{|c|c|c|c|}
\hline \multirow[b]{2}{*}{ Main effect of clomiphene citrate } & \multicolumn{3}{|c|}{ No. of ewes } \\
\hline & $\begin{array}{c}\text { In } \\
\text { oestrus }\end{array}$ & Ovulated & $\begin{array}{c}\text { Abnormal } \\
\text { uteri }\end{array}$ \\
\hline $\begin{array}{l}\text { Test } 1 \\
\text { Dose (mg) }(\mathrm{n}=12) \\
30 \\
90 \\
270\end{array}$ & $\begin{array}{l}7 \\
5 \\
9\end{array}$ & $\begin{array}{l}3 \\
0 \\
0\end{array}$ & $\begin{array}{r}2 \\
5 \\
11\end{array}$ \\
\hline $\begin{array}{c}P \text { linear } \\
\text { quadratic }\end{array}$ & $\begin{array}{l}\text { N.S. } \\
\text { N.S. }\end{array}$ & $\begin{array}{l}\text { N.S. } \\
\text { N.S. }\end{array}$ & $\begin{array}{l}<0.001 \\
\text { N.S. }\end{array}$ \\
\hline $\begin{array}{c}\text { Number of injections }(n=18) \\
\frac{1}{3}\end{array}$ & $\begin{array}{r}7 \\
14\end{array}$ & $\begin{array}{l}\mathbf{0} \\
\mathbf{3}\end{array}$ & $\begin{array}{l}9 \\
9\end{array}$ \\
\hline $\boldsymbol{P}$ & $<0.05$ & N.S. & N.S. \\
\hline $\begin{array}{l}\text { Timing of injections ( } \mathrm{n}=12) \\
\text { Without progestagen (1) } \\
\text { After cessation of progestagen (2) } \\
\text { Before cessation of progestagen (3) }\end{array}$ & $\begin{array}{l}4 \\
9 \\
8\end{array}$ & $\begin{array}{l}1 \\
1 \\
1\end{array}$ & $\begin{array}{l}4 \\
7 \\
7\end{array}$ \\
\hline $\begin{array}{c}P 1 \text { versus } \Sigma 2,3 \\
2 \text { versus } 3\end{array}$ & $\begin{array}{l}<0.05 \\
\text { N.S. }\end{array}$ & $\begin{array}{l}\text { N.S. } \\
\text { N.S. }\end{array}$ & $\begin{array}{l}\text { N.S. } \\
\text { N.S. }\end{array}$ \\
\hline Total, Test $1(\mathrm{~N}=36)$ & 21 & 3 & 18 \\
\hline $\begin{array}{l}\text { Test } 2 \\
\text { Dose } \underset{3.3}{(\mathrm{mg})}(\mathrm{n}=12) \\
10.0 \\
30.0\end{array}$ & $\begin{array}{r}6 \\
10 \\
11\end{array}$ & $\begin{array}{l}3 \\
0 \\
1\end{array}$ & $\begin{array}{r}0 \\
7 \\
11\end{array}$ \\
\hline $\begin{array}{l}P \text { linear } \\
\text { quadratic }\end{array}$ & $\begin{array}{l}<0.05 \\
\text { N.S. }\end{array}$ & $\begin{array}{l}\text { N.S. } \\
\text { N.S. }\end{array}$ & $\begin{array}{l}<0.001 \\
\text { N.S. }\end{array}$ \\
\hline $\begin{array}{c}\text { Number of injections }(\mathbf{n}=18) \\
\mathbf{1} \\
\quad P\end{array}$ & $\begin{array}{l}14 \\
13 \\
\text { N.S. }\end{array}$ & $\begin{array}{r}2 \\
2 \\
\text { N.S. }\end{array}$ & $\begin{array}{r}10 \\
8 \\
\text { N.S. }\end{array}$ \\
\hline Total, Test $2(\mathrm{~N}=36)$ & 27 & 4 & 18 \\
\hline $\begin{array}{l}\text { Controls } \\
\text { No treatment }(n=5) \\
\text { Progestagen only }(n=6)\end{array}$ & $\begin{array}{r}1 \\
\stackrel{4}{4} \\
\text { N.S. }\end{array}$ & $\begin{array}{r}2 \\
4 \\
\text { N.S. }\end{array}$ & $\begin{array}{c}\mathbf{0} \\
\stackrel{0}{0} \\
\text { N.S. }\end{array}$ \\
\hline
\end{tabular}

Note: There were no significant interactions. 
Whereas forty-eight of the seventy-two ewes treated with clomiphene were in oestrus, only seven ovulated, of which six were treated with the lowest dose level in each test. The incidence of ovulation was highly significantly different from that in the control ewes $\left(\chi_{1}^{2}=11.3 ; P<0.001\right)$. Furthermore, the ovaries of ewes which failed to ovulate showed little evidence of follicular growth.

TABLE 2

TEST 3-EFFEGTS ON PROGESTAGEN-PRIMED, SPAYED EWES OF TREATMENT WITH GLOMIPHENE, WITH OR WITHOUT OESTRADIOL BENZOATE (ODB)

\begin{tabular}{c|cccc|c}
\hline \multirow{2}{*}{$\begin{array}{c}\text { Dose of } O D B \\
(\mu \mathrm{g})\end{array}$} & \multicolumn{4}{|c|}{ Dose of clomiphene citrate $(\mathrm{mg})$} & \multirow{2}{*}{$\begin{array}{c}\text { Total } \\
(\mathrm{n}=28)\end{array}$} \\
\cline { 2 - 5 } & 0 & 1.0 & 3.3 & $10 \cdot 0$ & 2 \\
\hline 0 & 0 & 0 & 0 & 2 & 2 \\
\hline $15 \cdot 6$ & 1 & 3 & 4 & 5 & 13 \\
\hline Total $(\mathrm{n}=14)$ & 1 & 3 & 4 & 7 & 15 \\
\hline
\end{tabular}

Number of ewes in oestrus $(n=7)$.

Significance of effect of dose of clomiphene:

0 versus $\Sigma 1 \cdot 0,3 \cdot 3,10 \cdot 0 ; P<0.05$.

1.0 versus 3.3 versus $10 \cdot 0$ (linear); $P \fallingdotseq 0 \cdot 10$.

TABLE 3

TESTS 2 AND 3 - COMPARISON OF THE OESTROUS RESPONSE TO GLOMIPHENE OF PROGESTAGEN-PRIMED, ENTIRE, ANOESTROUS EWES AND SPAYED EWES

\begin{tabular}{|c|c|c|c|}
\hline \multirow{3}{*}{$\begin{array}{l}\text { Dose of clomiphene citrate } \\
\qquad(m g)\end{array}$} & \multicolumn{3}{|c|}{$\%$ ewes in oestrus } \\
\hline & \multirow{2}{*}{$\begin{array}{l}\text { Entire ewes* } \\
(n=12)\end{array}$} & \multicolumn{2}{|c|}{ Spayed ewes } \\
\hline & & $\begin{array}{c}+15 \cdot 6 \mu g O D B \\
\quad(n=7)\end{array}$ & $\begin{array}{c}+0 \mu g O D B \\
\quad(n=7)\end{array}$ \\
\hline $\begin{array}{l}0 \\
1 \cdot 0 \\
3 \cdot 3 \\
10 \cdot 0 \\
30 \cdot 0\end{array}$ & $\begin{array}{l}-\overline{-} \\
50 \cdot 0 \\
83 \cdot 0 \\
91 \cdot 7\end{array}$ & $\begin{array}{c}14 \cdot 3 \\
42 \cdot 9 \\
57 \cdot 1 \\
71 \cdot 4 \\
-\end{array}$ & $\begin{array}{c}0 \\
0 \\
0 \\
28 \cdot 6 \\
-\end{array}$ \\
\hline Regression coefficient (b) & $28 \cdot 2^{\circ} \pm 12 \cdot 3^{\circ}$ & \multicolumn{2}{|c|}{$17 \cdot 4^{\circ} \pm 11 \cdot 3^{\circ}$} \\
\hline
\end{tabular}

* Note: Only four of the thirty-six ewes ovulated.

Factors which affected the incidence of oestrus were: Test 1 , the number of injections and whether or not ewes were primed with progestagen; Test 2, the dose of clomiphene over the lower dose range.

A high incidence $(50 \%)$ of hydrops uteri occurred in each test, as a linear function of the dose of clomiphene $(P<0.001)$. Typically, the uteri were thinwalled, vascular and distended to four- or five-times normal size with clear intraluminal fluid (Plate 1).

Spayed ewes-Test 3

Table 2 shows that fifteen ewes exhibited oestrus, two of twenty-eight 
PLATE 1

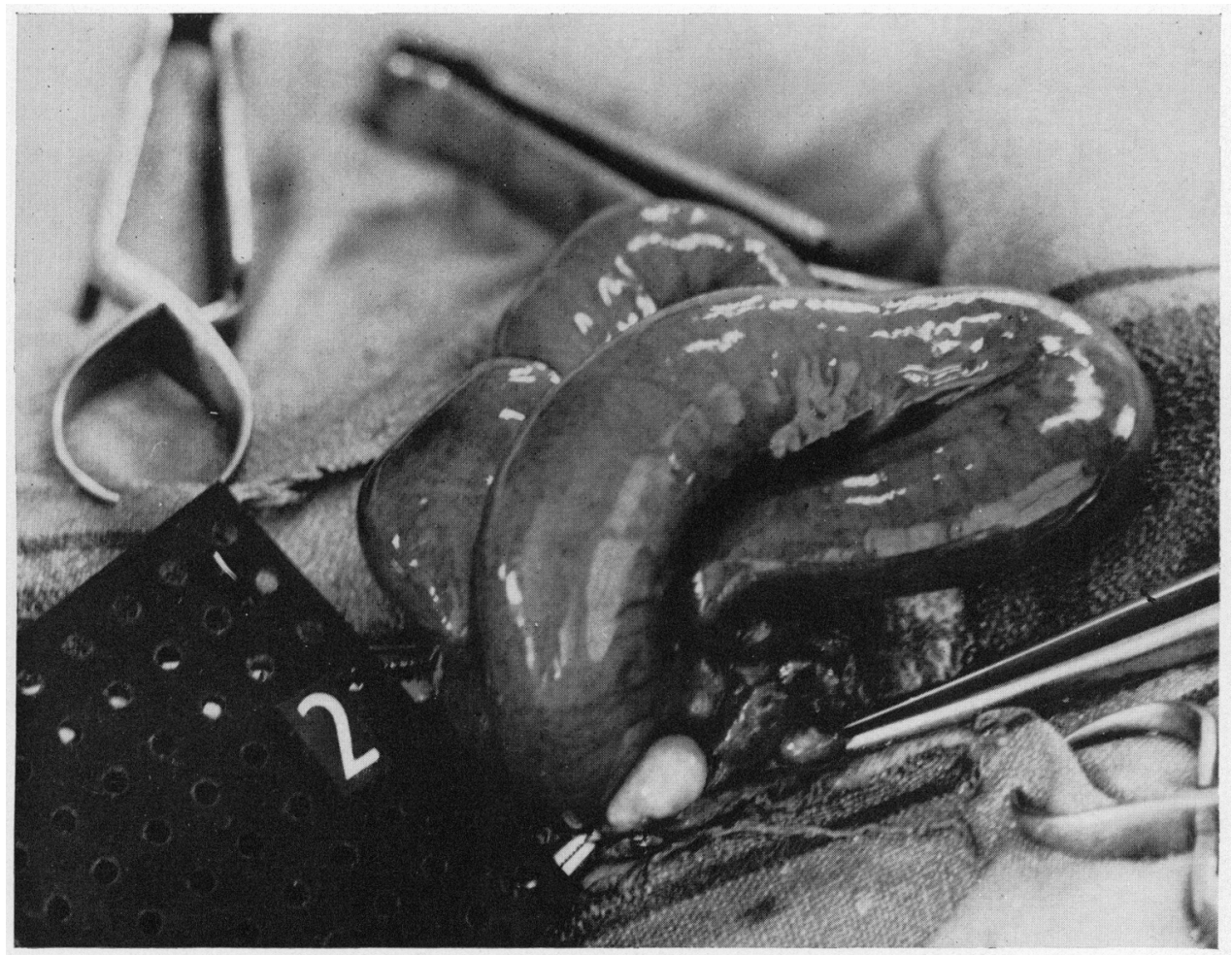

Cienital tract of a cwe approximately $80 \mathrm{hr}$ after injection of $90 \mathrm{mg}$ clomiphene citrate. Note the thin-walled, fluid-filled uterus and the inactive ovary. 
untreated with ODB and fifteen of twenty-eight which received 15.6 $\mu \mathrm{g}$ $(P<0.001)$. There was a significant effect of clomiphene on the incidence of oestrus $(P<0 \cdot 05)$ and an effect of dose which approached significance $(P \fallingdotseq 0 \cdot 10)$.

\section{Oestrus - dose response effect in entire and spayed ewes}

Table 3 compares the oestrous response in spayed and entire ewes, over comparable dose ranges of clomiphene. The regression coefficients are indistinguishable and the overall pattern of response in the entire ewes is similar to that of the spayed ewes in which clomiphene treatment is supplemented by a single injection of $15 \cdot 6 \mu \mathrm{g}$ ODB.

\section{DISCUSSION}

Clomiphene acts in the ewe as a weak oestrogen. In entire ewes, it inhibits ovulation and induces oestrus without ovulation. In spayed ewes, it induces oestrus if given at sufficiently high doses $(\geqslant 10 \mathrm{mg}$ ) and it augments the oestrous response to small doses of ODB. This augmentation of oestrogen-induced behavioural oestrus is in contrast to its anti-oestrogenic activity on uterotrophic effects in rats (Roy, Greenblatt \& Mahesh, 1964) and mice (Holtkamp, Staples, Greslin \& Davis, 1966). The dose-response pattern in spayed and entire ewes is similar. The slope of the dose-response line is much less steep than that for other oestrogens (Robinson \& Reardon, 1961), particularly the natural steroids, suggesting a qualitative difference in action. This difference is confirmed by its effect on the uterus. In Test $2,3.3 \mathrm{mg} /$ day resulted in oestrus in six of twelve treated ewes, ovulation in three, and hydrops uteri in none. A dose of $10 \mathrm{mg} /$ day resulted in oestrus in ten ewes of twelve treated, ovulation in none and hydrops uteri in seven. These uteri were grossly abnormal (Plate 1) and the pattern was quite dissimilar from the uterine hyperplasia and hypertrophy associated with normal oestrogenic activity, particularly in the rapid and copious accumulation of clear intraluminal fluid.

The physiological effects of clomiphene in the ewe differ markedly from those observed in other species such as the rat and man. Holtkamp, Greslin, Root \& Lerner (1960), Holtkamp, Davis \& Rhoads (1961) and Barnes \& Meyer (1962) presented evidence that clomiphene inhibits secretion of gonadotrophin and ovulation in adult rats. More recently, Coppola \& Perrine (1965) and Coppola, Leonardi \& Ringler (1966) have shown that, while higher doses (1.5 $\mathrm{mg} / \mathrm{kg} /$ day $)$ inhibit ovulation, lower doses $(0.5 \mathrm{mg} / \mathrm{kg} /$ day $)$ stimulate gonadotrophic activity. Even at the higher doses, these authors observed "intense follicular stimulation" and presumed the absence of corpora lutea to be due to inhibition of release of LH. Docke (1969) induced ovulation by clomiphene in female rats made anovulatory by post-natal injections of androgen, continuous illumination or lesions in the hypothalamus. He concluded that simulation of the pituitary by clomiphene was dependent upon the maintenance of activity of the cyclic gonadotrophin-controlling region of the medial pre-optic anterior hypothalamus.

In man, clomiphene induces massive ovarian hypertrophy (Southam \& Janovski, 1962), due according to Roy, Greenblatt, Mahesh \& Jungck (1963) 
to a stimulation of release of pituitary FSH. Furthermore, it appears to suppress the ovulation inhibitory action of oestrogen (Pincus, 1965). By direct contrast, all ovarian activity was inhibited at all dose levels used in our studies in the ewe (range 0.03 to $6.8 \mathrm{mg} / \mathrm{kg} /$ day): follicles failed to develop, ovulations did not occur and corpora lutea were not formed. The only thread of evidence for the stimulation of gonadotrophic activity was the higher incidence of heat in the entire than in the spayed ewe at comparable dose levels of clomiphene, which could be interpreted as due to FSH-stimulated ovarian oestrogen. There are many other ways of accounting for this relatively slight quantitative difference and the lack of difference in the slope of the regression of response on dose suggests no such stimulation. Were it present, the slope would be steeper in the entire ewe.

The ewes in this experiment were exhibiting some ovarian activity; six ovulated of eleven which were untreated or which received only progestagen, five with oestrus. Hence, anoestrus was not 'deep' and, at the months involved, ewes could be expected to be emerging from the anoestrous state and to be susceptible to pituitary stimulation. In fact, clomiphene did not stimulate pituitary activity: it was suppressed and the incidence of anoestrus increased.

It is concluded that clomiphene has no pituitary-stimulatory or gonadotrophin-like activity in the sheep. It acts as a weak oestrogen but differs qualitatively from true oestrogens in its effect on the uterus.

\section{ACKNOWLEDGMENTS}

We are indebted to J. Ellsmore for technical assistance; to Dr W. Distin-Morgan of the Wm. S. Merrell Company and Dr G. E. Short of G. D. Searle and Co. for the donations of clomiphene citrate and Cronolone, respectively. Financial support was received from the Australian Wool Board.

\section{REFERENCES}

Barnes, L. E. \& MEYer, R. K. (1962) Effects of ethamoxytriphetol, MRL-37, and clomiphene on reproduction in rats. Fert. Steril. 13, 472.

Coppola, J. A., Leonardi, R. G. \& Ringler, I. (1966) Reversal of the effects of anti-oestrogens and norethynodrel on gonadotrophin-induced ovulation in rats. F. Reprod. Fert. 11, 65.

Coppola, J. A. \& Perrine, J. W. (1965) The influence of two nonsteroidal antiestrogens on vaginal opening and PMs-induced ovulation in rats. Endocrinology, 76, 865.

Docke, F. (1969) Ovulation-inducing action of clomiphene citrate in the rat. 7. Reprod. Fert, 18, 135.

Greenblatt, R. B. (1961) Chemical induction of ovulation. Fert. Steril. 12, 402.

Holtkamp, D. E., Davis, R. H. \& Rhoads, J. E. (1961) Effect of chloramiphene on fertility and ovulation. Fedn Proc. Fedn Am. Socs exp. Biol. 20, 419.

Holtkamp, D. E., Greslin, J. C., Root, G. A. \& Lerner, L. J. (1960) Gonadotrophin inhibiting and anti-fecundity effects of chloramiphene. Proc. Soc. exp. Biol. Med. 105, 197.

Holtkamp, D. E., Staples, R. E., Greslin, J. G. \& Davis, R. H. (1966) Pharmacodynamics of clomiphene in animals. Proc. Vth World Congr. Fertil. Steril., Stockholm.

Pincus, G. (1965) The control of fertility, Chap. 10, pp. 211-212. Academic Press, New York.

RADFord, H. M., WATsOn, R. H. \& WOOD, G. F. (1960) A crayon and associated harness for the detection of mating under field conditions. Aust. vet. 7. 36, 57.

RoBINson, T. J. (1965) Use of progestagen-impregnated sponges inserted intravaginally or subcutaneously for the control of the oestrous cycle in the sheep. Nature, Lond. 206, 39.

Rosinson, T. J. \& REardon, T. F. (1961) The activity of a number of oestrogens as tested in the spayed ewe. F. Endocr. 23, 97. 
Rox, S., Greenblatt, R. B. \& Mahesh, V. B. (1964) Effects of clomiphene on the physiology of reproduction in the rat. II. Its oestrogenic and anti-oestrogenic actions. Acta endocr., Copenh. 47, 756 .

Roy, S., Grgenblatt, R. B., Mahesh, V. B. \& Jungck, E. G. (1963) Clomiphene citrate: further observations on its use in induction of ovulation in the human and on its mode of action. Fert. Steril. 14, 575.

Southam, A. L. \& JANovski, N. A. (1962) Massive ovarian hyperstimulation with clomiphene citrate. J. Am. med. Ass. $181,443$.

SWYER, G. I. M. (1963) Induction of ovulation in the human-older and newer approaches. Proc. $R$. Soc. Med. 56, 39. 